\title{
Pseudotumor cerebri during Cushing's disease treatment with ketoconazole
}

\author{
Pseudotumor cerebral durante o tratamento de \\ doença de Cushing com cetoconazol
}

Fabiola Costenaro', Ticiana C. Rodrigues', Nelson P. Ferreira², Tiago G. da Costa ${ }^{3}$, Tiago Schuch', Vitor Boschi', Mauro A. Czepielewski ${ }^{1,4}$

${ }^{1}$ Endocrine Division, Hospital de Clínicas de Porto Alegre, Porto Alegre, RS, Brazil

${ }^{2}$ Neurosurgery Division, Hospital São José, Universidade Federal de Ciências da Saúde de Porto Alegre (UFCSPA), Porto Alegre, RS, Brazil ${ }^{3}$ Ophtalmology Division, Hospital de Clínicas de Porto Alegre,

Porto Alegre, RS, Brazil

${ }^{4}$ Universidade Federal do Rio Grande do Sul (UFRGS), Porto Alegre, RS, Brazil

Correspondence to:

Mauro A. Czepielewski

Hospital de Clínicas de Porto

Alegre,

Serviço de Endocrinologia

Rua Ramiro Barcellos, 2350, prédio

12,40 andar

90035-003 - Porto Alegre, RS,

Brazil

maurocze@terra.com.br

Received on Sep/26/2010 Accepted on Dec/9/2010

\section{SUMMARY}

Benign intracranial hypertension (Pseudotumor cerebri) has been described as related to the reduction in steroid levels in Cushing's disease (CD), especially after surgical remission. Ketoconazole is a common and effective adjuvant therapy for hypercortisolism, but the major concern is liver enzyme dysfunction. We describe here the case of a 12-year old girl with CD who developed benign intracranial hypertension during treatment with ketoconazole. She presented headache, vomiting, a black spot on her right temporal visual field, and signs of elevated intracranial pressure. Pituitary image was normal on magnetic resonance image (MRI), and all symptoms improved after treatment with acetazolamide. We call attention to the diagnosis of this disorder in CD patients, especially children on ketoconazole treatment, because it could be confounded with adrenal insufficiency and lead to definitive severe visual impairment. Arq Bras Endocrinol Metab. 2011;55(4):284-7

\section{SUMÁRIO}

Hipertensão intracraniana benigna (Pseudotumor cerebral) tem sido descrita relacionada à redução dos níveis de esteroides séricos na doença de Cushing (DC), especialmente após a remissão cirúrgica. $O$ cetoconazol é uma opção efetiva e de uso rotineiro como adjuvante na terapêutica do hipercortisolismo, tendo como paraefeito mais temido a toxicidade hepática. Relatamos o caso de uma menina com 12 anos de idade portadora de DC que desenvolveu hipertensão intracraniana benigna durante tratamento com cetoconazol. Apresentou-se com cefaleia, vômitos, comprometimento do campo visual temporal direito e sinais de hipertensão intracraniana. A ressonância magnética (RM) de hipófise era normal e todos os sinais e sintomas resolveram-se com uso de acetazolamida. Chamamos a atenção para esse diagnóstico nos pacientes com DC, especialmente crianças, em tratamento com cetoconazol, porque ele pode ser confundido com insuficiência adrenal e causar comprometimento visual severo e definitivo. Arq Bras Endocrinol Metab. 2011;55(4):284-7

\section{INTRODUCTION}

C ushing's disease (CD) patients may be a group at risk for benign intracranial hypertension as a consequence of the long suppression of normal pituitary corticotrophs, exposure to high circulating levels of serum cortisol, and abrupt and intense drop of cortisol levels with intervention. Patients effectively treated for hypercortisolism present reduction in the levels of these hormones, what may affect control of brain volume and lead to increased intracranial pressure (1). It is thought that altered cerebrospinal fluid (CSF) absorption gradi- ent across the arachnoid villi may be the primary factor in resetting intracranial fluid compartments (2). There are some reports of benign intracranial hypertension, also called pseudotumor cerebri, associated with CD as a result of the reduction in corticosteroid levels after treatment with metyrapone, aminoglutethimide $(1,3)$, and mitotane (4), or after a reduction in steroid levels in patients treated with pituitary surgery $(3,5-7)$. Adrenal deficiency symptoms, such as headache and nausea, can be manifestations of intracranial hypertension in patients who have recently had the levels of exogenous or endogenous corticosteroids reduced. 
Pseudotumor cerebri syndrome is characterized by headache, nausea/vomiting, papilledema and elevated CSF pressure $\left(>200 \mathrm{~mm} \mathrm{H}_{2} \mathrm{O}\right.$ ), with normal neurological examination (except for sixth nerve palsy and other problems secondary to intracranial hypertension), normal brain image, and normal CSF content $(8,9)$. The major threat to patients with pseudotumor cerebri is loss of vision. Severe deficits occurred in 4\%$12 \%$ of patients in a follow-up of four series (10). Usually, pseudotumor cerebri symptoms occur between 2 and 4 weeks after treatment of hypercortisolism or withdrawal of steroid replacement $(5,6,11)$.

Recently, Kiehna and cols. reported seven cases of pseudotumor cerebri in 941 patients with CD who had pituitary surgery, a prevalence of about $0.7 \%$. All these cases were diagnosed among pediatric patients (prevalence of $3 \%$ ) during the first year after surgical treatment (3).

Here, we present a case of pseudotumor cerebri in a young female with $\mathrm{CD}$ during treatment with ketoconazole to manage hypercortisolism.

\section{CASE REPORT}

A 12-year old girl was investigated for aggravated obesity. She presented centripetal obesity, moon face and supraclavicular fat pad at her first visit: weight $61 \mathrm{~kg}$, height $151 \mathrm{~cm}$, body mass index $26.7 \mathrm{~kg} / \mathrm{m}^{2}$, Tanner stage M3P3. Cushing's syndrome was suspected because of elevated 24h-urinary free cortisol (UFC) 538 $\mathrm{ug} / \mathrm{dL}$ (14,848 nmol/L) [normal range: $37-136 \mathrm{ug} / \mathrm{dL}$ (normal range: $1,021-3,753 \mathrm{nmol} / \mathrm{L}$ )], midnight serum cortisol $14.37 \mathrm{ug} / \mathrm{dL}(397 \mathrm{nmol} / \mathrm{L})$ and overnight 1 mg dexamethasone suppression of $13.2 \mu \mathrm{g} / \mathrm{dL}$ (364 nmol/L) [normal: $<1.8 \mu \mathrm{g} / \mathrm{dL}(50 \mathrm{nmol} / \mathrm{L})]$. Plasma ACTH was $58 \mathrm{pg} / \mathrm{mL}(12.76 \mathrm{pmol} / \mathrm{L})$ [normal range: $10-52 \mathrm{pg} / \mathrm{dL}$, (normal range: $2.2-11.4 \mathrm{pmol} / \mathrm{L}$ )]. Pituitary magnetic resonance image (MRI) was normal.

A bilateral simultaneous inferior petrosal sinus sampling was performed and showed significant plasma ACTH response to CRH, from $26.6 \mathrm{pg} /$ $\mathrm{mL}(5.85 \mathrm{pmol} / \mathrm{L})$ to $1,250 \mathrm{pg} / \mathrm{ml}(275 \mathrm{pmol} / \mathrm{L})$ (Table 1), determining CD diagnosis. Ketoconazole was administered to control the disease before transsphenoidal surgery. Treatment started with a $200 \mathrm{mg} /$ day dose, and was gradually increased for 8 months, based on Cushing's syndrome parameters. At the $800 \mathrm{mg} /$ day dose, the patient recovered her growth rate, lost $10 \%$ of body weight and normalized her 24-h UFC (Table 2).
Four weeks after the last highest dose of ketoconazole, the patient reported a frontal headache with purulent nasal discharge, which led to sinusitis diagnosis and was treated with amoxicillin. Six weeks after this first presentation, the patient complained of frontal headache, myalgias and vomiting, a picture that was interpreted as recurrent sinusitis and treated with azithromycin for 6 days. No symptomatic relief was observed, and she reported a black spot on her right temporal visual field. Ophthalmologic evaluation identified significant bilateral papilloedema (Figure 1A). Brain MRI remained normal and lumbar puncture confirmed elevated CSF opening pressure of $350 \mathrm{~mm} \mathrm{H}_{2} \mathrm{O}$, with normal liquor content. All symptoms and papilloedema were solved after treatment with acetazolamide at $750 \mathrm{mg} /$ day dose (Figure 1B). It should be noted that ketoconazole dose was not decreased during the treatment.

\section{DISCUSSION AND CONCLUSION}

Scattered cases of benign intracranial hypertension or pseudotumor cerebri have been described after CD control with pituitary surgery, or administration of drugs, including metyrapone, aminoglutethimide and mitotane $(1,3-4)$. This is the first well-characterized report of pseudotumor cerebri in a patient treated with ketoconazole for hypercortisolism.

Ketoconazole is an antifungal agent, an imidazole derivative, which has putative extra-adrenal actions $(12,13)$, and shows inhibitory effects on adrenal and gonadal steroidogenesis linked to the restriction of cytochrome P-450 enzymes, including P450 (scc), P450 (17 $\alpha$ lyase), and P450 (11 $\beta / 18)$. In CD, ketoconazole is used before surgery, as adjuvant therapy, or in subjects who refused or had any contraindications to surgery (12). There is substantial accumulated experience on the use of ketonazole in hypercortisolism because of its effectiveness as monotherapy, and its favorable side effect profile (14). Common side effects are gastrointestinal upset and skin rashes. Liver enzyme dysfunction may occur in up to $10 \%$ of the cases. Recommended starting dose is $200 \mathrm{mg}$ twice a day, increasing to $1,200 \mathrm{mg} /$ day, divided in four doses $(15,16)$.

Castinetti and cols. (12) described thirty-eight patients with CD treated for hypercortisolism with ketoconazole. Rare side effects were observed, inclu- 
ding diarrhea and moderate liver enzyme dysfunction, when using 1,200 mg/day. No adrenal insufficiency or pseudotumor cerebri were observed in this adult sample. Moreover, ketoconazole was used for up to 13 years in a cohort of fifty four patients with $\mathrm{CD}$, with few side-effects: $18 \%$ showed adrenal insufficiency, and no case of pseudotumor cerebri was reported, including in 14-year old patients (16). Recently, ketoconazole was associated with cabergoline in part of a cohort of patients with CD unsuccessfully treated with transspheinodal surgery (17), and no cases of benign intracranial hypertension were

Table 1. Bilateral simultaneous inferior petrosal sinus sampling with $\mathrm{CRH}$

\begin{tabular}{lccc}
\hline & $\begin{array}{c}\text { Periphery } \\
\text { ACTH }\end{array}$ & $\begin{array}{c}\text { Right side } \\
\text { ACTH }\end{array}$ & $\begin{array}{c}\text { Left side } \\
\text { ACTH }\end{array}$ \\
\hline $0 \mathrm{~min} \mathrm{pg} / \mathrm{ml}(\mathrm{pmol} / \mathrm{L})$ & $99.4(21.8)$ & $26.6(5.8)$ & $16.4(3.6)$ \\
$3 \mathrm{~min} \mathrm{pg} / \mathrm{ml}(\mathrm{pmo} / \mathrm{L})$ & $144(31.7)$ & $737(162.2)$ & $36.5(8.0)$ \\
$5 \mathrm{~min} \mathrm{pg} / \mathrm{ml}(\mathrm{pmol} / \mathrm{L})$ & $236(52.0)$ & $>1250(>275)$ & $38.7(8.5)$ \\
$10 \mathrm{~min} \mathrm{pg} / \mathrm{ml}(\mathrm{pmol} / \mathrm{L})$ & $269(59.0)$ & $960(211.2)$ & $79.7(17.5)$ \\
$20 \mathrm{~min} \mathrm{pg} / \mathrm{ml}(\mathrm{pmol} / \mathrm{L})$ & $270(59.4)$ & $1160(255)$ & $270(59.4)$ \\
\hline
\end{tabular}

ACTH performed by Immulite ${ }^{\circledast}$ Immunoassay system. detected, although full normalization UFC excretion was targeted in two-thirds of the patients.

Adrenal insufficiency has been described with low doses of ketoconazole - from 200 to $400 \mathrm{mg} /$ day (16). Our patient was using an $800 \mathrm{mg} /$ day dose, which could also cause an adrenal insufficiency crisis. Nonetheless, results of her laboratory exams at 800 $\mathrm{mg} /$ day dose showed normalized UFC excretion and serum cortisol levels (Table 2 ). Her condition improved with the treatment for intracranial hypertension, and the dose of ketoconazole was not reduced.

Abrupt cessation of steroid administration may cause a substantial increase in resistance to cerebrospinal fluid flow $(18,19)$. However, our patient was using ketoconazole for a long period and the dose was increased slowly, as showed in table 2 .

In summary, this case emphasizes the association between pseudotumor cerebri and ketoconazole therapy in CD, especially for the treatment of hypercortisolism in children, as this is a group of patients more susceptible to and at major risk for this disorder.

Table 2. Laboratory results according to Ketoconazole (Kt) doses

\begin{tabular}{|c|c|c|c|c|c|}
\hline & At baseline & $\begin{array}{l}\text { Kt } 200 \mathrm{mg} / \mathrm{d} \\
1^{\text {st }} \text { month }\end{array}$ & $\begin{array}{l}\text { Kt } 400 \mathrm{mg} / \mathrm{d} \\
2^{\text {nd }} \text { month }\end{array}$ & $\begin{array}{l}\text { Kt } 600 \mathrm{mg} / \mathrm{d} \\
5^{\text {th }} \text { month }\end{array}$ & $\begin{array}{l}\text { Kt } 800 \mathrm{mg} / \mathrm{d} \\
8^{\text {th }} \text { month }\end{array}$ \\
\hline 24 hUFC ug/dL (nmol/L) & 538 (14849) & $282(7783)$ & $110(3036)$ & $54.6(1506)$ & $25(690)$ \\
\hline ACTH pg/mL (pmol/l) & $58(12.8)$ & $132(29)$ & $177(39)$ & $149(33)$ & $186(41)$ \\
\hline Cortisol ug/dl (nmol/l) & $9.1(251)$ & $22.7(626)$ & $18(497)$ & $17(469)$ & $7(193)$ \\
\hline SDHE ug/dl (nmol/l) & $64(1.73)$ & $86.2(2.32)$ & $137(3.70)$ & $86.2(2.32)$ & $58.4(1.57)$ \\
\hline
\end{tabular}

UFC: urinary free cortisol, Roche Elecsys Immunoassay, normal range: $37-136 \mathrm{ug} / \mathrm{dL}$ (normal range: 1021-3753 nmol/L); ACTH: Immulite ${ }^{\circledR}$ Immunoassay-DPC, normal range: 10-52 pg/mL (normal range: 2.2-11.4 pmol/L); cortisol: Electrochemiluminescence. Modular-Roche, normal range: 6.2-19.4 ug/dL (normal range: 171-541 nmol/L); SDHEA: Electrochemiluminescence. Modular-Roche, normal range: $33.9-280 \mathrm{ug} / \mathrm{dl}$ (normal range: $0.91-7.6 \mathrm{nmol} / \mathrm{L}$ ).
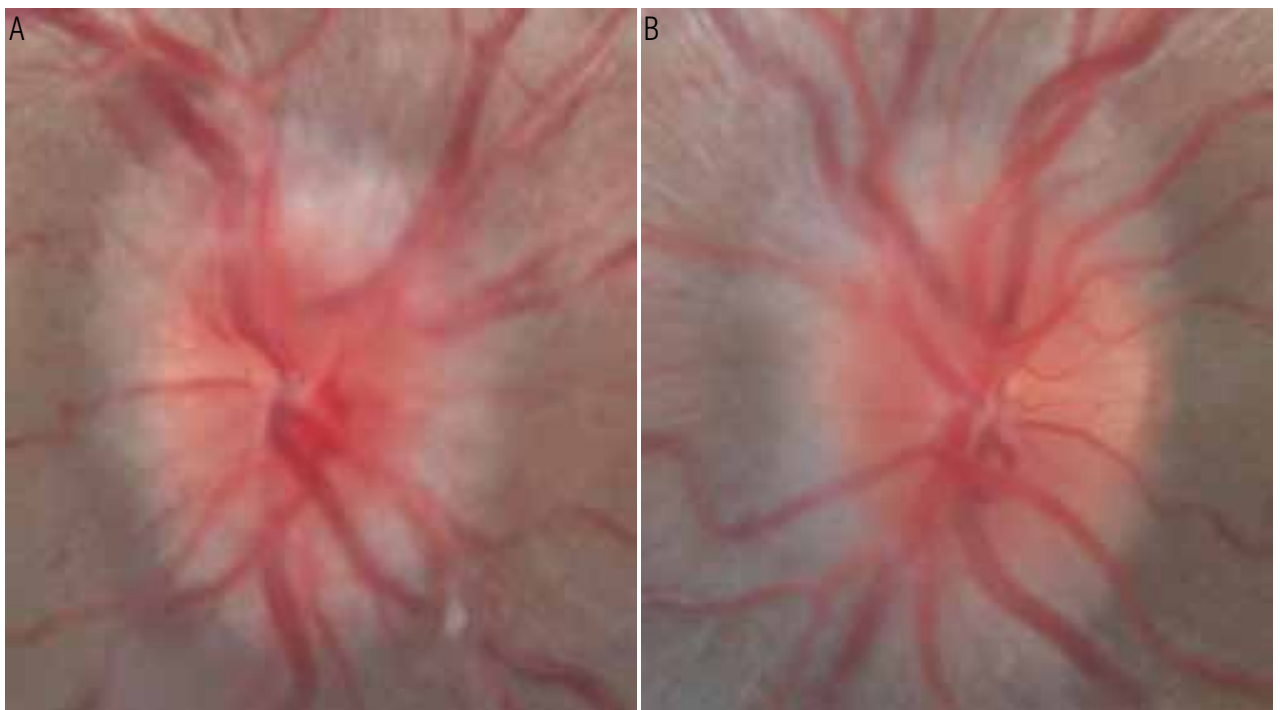

Figure 1. (A) Patient with papilloedema. (B) Resolution of papilloedema after treatment. 
Acknowledgements: We would like to thank Davidson Alba and Paula B. de Lima for helping us to assist this patient. FC was supported by a scholarship from CAPES (Coordenação de Aperfeiçoamento de Pessoal de Nível Superior), a Brazilian funding agency of the Ministry of Education.

Disclosure: no potential conflict of interest relevant to this article was reported.

\section{REFERENCES}

1. Newman PK, Snow M, Hudgson P. Benign intracranial hypertension and Cushing's disease. Br Med J. 1980;281(6233):113.

2. Johnston I, Paterson A. Benign intracranial hypertension. II. CSF pressure and circulation. Brain. 1974;97(2):301-12.

3. Kiehna EN, Keil M, Lodish M, Stratakis C, Oldfield EH. Pseudotumor cerebri after surgical remission of Cushing's disease. J Clin Endocrinol Metab. 2010;95(4):1528-32.

4. Marechaud R, Boissonnot M, Holderer-Fieuzal S, Gouet D, Boissonnot $\mathrm{L}$. [Idiopathic intracranial hypertension during treatment of Cushing's disease with mitotane]. Presse Med. 1987;16(42):2131.

5. Martin NA, Linfoot J, Wilson CB. Development of pseudotumor cerebri after the removal of an adrenocorticotropic hormone-secreting pituitary adenoma: case report. Neurosurgery. 1981;8(6):699-702.

6. Rickels MR, Nichols CW. Pseudotumor cerebri in patients with Cushing's disease. Endocr Pract. 2004;10(6):492-6.

7. Parfitt VJ, Dearlove JC, Savage D, Griffith HB, Hartog M. Benign intracranial hypertension after pituitary surgery for Cushing's disease. Postgrad Med J. 1994;70(820):115-7.

8. Lessell S. Pediatric pseudotumor cerebri (idiopathic intracranial hypertension.) Surv Ophthalmol. 1992;33:155-66.
9. Klein S, Romijn JA. Obesity. In: Kronenberg HM, Melmed S, Polonsky KS, Larsen PR, eds. Williams Textbook of Endocrinology: 11th ed. Philadelphia: Saunders; 2008; p. 1572.

10. Ahlskog JE, O'Neill BP. Pseudotumor cerebri. Ann Intern Med. 1982;97(2):249-56.

11. Weissman MN, Page LK, Bejar RL. Cushing's disease in childhood: benign intracranial hypertension after trans-sphenoidal adenomectomy. Neurosurgery. 1983;13(2):195-8.

12. Castinetti $F$, Morange I, Jaquet P, Conte-Devolx B, Brue T. Ketoconazole revisited: a preoperative or postoperative treatment in Cushing's disease. Eur J Endocrinol. 2008;158(1):91-9.

13. Sonino $\mathrm{N}$. The use of ketoconazole as an inhibitor of steroid production. N Engl J Med. 1987;317(13):812-8.

14. Zollner E, Delport $S$, Bonnici F. Fatal liver failure due to ketoconazole treatment of a girl with Cushing's syndrome. J Pediatr Endocrinol Metab. 2001;14:335-8.

15. Sonino N, Boscaro M, Paoletta A, Mantero F, Ziliotto D. Ketoconazole treatment in Cushing's syndrome: experience in 34 patients. Clin Endocrinol (Oxf). 1991;35:347-52.

16. Moncet D, Morando DJ, Pitoia F, Katz SB, Rossi MA, Bruno OD. Ketoconazole therapy: an efficacious alternative to achieve eucortisolism in patients with Cushing's syndrome. Medicina (B Aires). 2007;67(1):26-31.

17. Vilar L, Naves LA, Azevedo MF, Arruda MJ, Arahata CM, Moura E, et al. Effectiveness of cabergoline in monotherapy and combined with ketoconazole in the management of Cushing's disease. Pituitary. 2010;13(2):123-9.

18. Johnson I, Gilday DL, Hendrick EB. Experimental effects of steroids and steroid withdrawal on cerebrospinal fluid absorption. J Neurosurg. 1975;42:690-5.

19. Johnston I. Reduced C.S.F. absorption syndrome. Reappraisal of benign intracranial hypertension and related conditions. Lancet. 1973;2(7826):418-21. 